Rosa A. Castillo Ruiz · Carmen Herrera

Marc Ghislain · Christiane Gebhardt

\title{
Organization of phenylalanine ammonia lyase (PAL), acidic $P R-5$ and osmotin-like (OSM) defence-response gene families in the potato genome
}

Received: 21 March 2005/ Accepted: 27 April 2005/Published online: 16 August 2005

(C) Springer-Verlag 2005

\begin{abstract}
Defence-response (DR) genes are candidates for the genetic functions underlying quantitative resistance to plant pathogens. The organization of three DR gene families encoding phenylalanine ammonia lyase (PAL), acidic PR-(pathogenesis-related) protein 5, and basic PR-5, or osmotin-like (OSM), proteins was studied in the potato genome. A bacterial artificial chromosome (BAC) library containing $\sim 50,000$ clones was constructed from high-molecular weight genomic DNA of the diploid potato clone PD59, a hybrid between Solanum tuberosum and $S$. phureja. BAC clones carrying one or more copies of the DR genes were identified and characterized by Southern hybridization, sequence analysis and genetic mapping. $P A L$, acidic $P R-5$ and $O S M$ (basic $P R-5$ ) genes were all organized into gene families of varying complexity. The $P A L$ gene family consisted of at least 16 members, several of which were physically linked. Four acidic $P R-5$ homologous were localized to a $45-\mathrm{kb}$ segment on potato chromosome XII. One of these, $P R-5 / 319$, codes for the acidic thaumatin-like protein $\mathrm{C}$ found in intercellular fluids of potato. Nine $O S M$ genes were organized at two loci: eight form a 90-kb cluster on chromosome VIII, and a single gene was found on chromosome XI. The topology of a phylogenetic tree based on PR-5 and OSM protein sequences from Solanaceae suggests a mode of evolution for these gene families. The results will form the basis for further studies on the potential role of these defencerelated loci in quantitative resistance to pathogens.
\end{abstract}

Communicated by M.-A. Grandbastien

R. A. Castillo Ruiz · C. Gebhardt ( $\square)$

Max-Planck Institute for Plant Breeding Research, Carl von Linne Weg 10, 50829 Cologne, Germany

E-mail: gebhardt@mpiz-koeln.mpg.de

C. Herrera · M. Ghislain

Centro International de la Papa CIP, Apartado 1558, 12 Lima, Peru
Keywords Defence-response genes - BAC library Phenylalanine ammonia lyase $\cdot$ Acidic PR-5 .

Osmotin-like

\section{Introduction}

Natural genetic variation for plant resistance to plant pathogens such as viruses, bacteria and fungi appears in two forms: as a qualitative resistance response to a specific pathogen triggered by a single $R$ gene, or as quantitative or partial resistance, which is controlled by an unknown number of genes. The map positions of genes controlling quantitative resistance can be delimited by quantitative trait locus (QTL) analysis using molecular markers. However, genes underlying quantitative resistance have not yet been identified at the molecular level, whereas $R$ genes and genes controlling the various defence responses triggered by them have been studied extensively (reviewed in Kombrink and Somssich 1995; McDowell and Woffenden 2003). In potato, a number of $R$ genes and QTLs for pathogen resistance have been localized on molecular genetic maps. Some $R$ loci co-localize with resistance QTLs (Gebhardt and Valkonen 2001; Simko 2002; Bonierbale et al. 2003), suggesting that quantitative resistance may result from allelic series of $R$ genes or from clustered families of $R$ gene homologues (Leonards-Schippers et al. 1994). The potato molecular map also contains a number of defence-response (DR) loci, which have been identified by restriction fragment length polymorphism (RFLP) mapping, using cloned DR genes from potato and tobacco as probes (Leonards-Schippers et al. 1994; Gebhardt et al. 2001). Few of these DR loci are located in the same map segments as resistance QTL.

Quantitative trait loci for resistance to late blight caused by the oomycete Phytophthora infestans have been mapped to six potato chromosomes in a diploid interspecific hybrid population derived from a cross between the diploid Solanum phureja and dihaploid 
S. tuberosum ssp. tuberosum (the 'PD family'; Ghislain et al. 2001). Markers were developed for a series of DR genes and were found to be linked to QTLs for late blight resistance in the PD family (Trognitz et al. 2002). Based on their functional role in resistance to pathogens, and the observed genetic correlations with resistance QTLs, both $R$ gene homologues and defenceresponse genes are candidates for the genes that underly quantitative resistance (Leister et al. 1996; Faris et al. 1999; Li et al. 1999; Wang et al. 2001; Pflieger et al. 2001).

The gene(s) underlying a given QTL are expected to be present as molecularly and functionally diverse alleles in the genetic material used for QTL mapping. The causal role of a candidate gene in the trait governed by the QTL has to be confirmed by cloning the alleles and using them as transgenes for quantitative complementation analysis in suitable genetic backgrounds. A candidate locus may be complex, however, containing candidate gene families rather than single genes (Trognitz et al. 2002; Paal et al. 2004). The use of large DNA segments for functional complementation, such as the plasmid with a $90-\mathrm{kb}$ insertion used by Ercolano et al. (2004), helps to simplify this task. However, a specific large-insert library must be constructed for the genotype that is heterozygous for the QTL and candidate-gene alleles.

As a prerequisite for the further evaluation of the role of DR genes in quantitative resistance to late blight in the PD family, we have constructed a bacterial artificial chromosome (BAC) library from high-molecular-weight DNA obtained from one hybrid clone of the PD family. Using this BAC library, we determined the structure and genomic organization of three families of defence-response genes encoding phenylalanine ammonium lyase (PAL; a key enzyme in the phenylpropanoid pathway leading to the accumulation of phytoalexins), osmotin-like (OSM) proteins, and acidic pathogenesis related protein 5 (PR-5). These three gene families were selected from the large number of potential DR candidate genes based on their putative linkage to QTL for late blight resistance that have been mapped in the PD population.

\section{Materials and methods}

Plant material

The diploid potato clone PD59 was used to construct the BAC library. PD59 is one of 246 hybrids (the PD population) derived from an inter-specific cross between $S$. phureja (clone CHS-625) and dihaploid S. tuberosum ssp. tuberosum (line PS-3) (Ghislain et al. 2001). PD59 was selected for its resistance to late blight and, based on linked marker alleles, for combining positive effects at QTLs on chromosomes III, V, VII, VIII, XI and XII. PD59 was obtained as an in vitro culture from the
International Potato Center (CIP, Lima, Peru). Plants were propagated from stem cuttings in MS medium (Murashige and Skoog 1962). Rooted plantlets were transferred to the greenhouse and grown under normal daylight conditions. Before harvesting leaves for protoplast isolation, plants were kept in the dark for 3 days to decrease leaf starch content. For mapping purposes, two diploid populations were used. The PD population, in which QTLs for late blight resistance have been mapped (Ghislain et al. 2001) and population F1840, which consists of $92 \mathrm{~F} 1$ individuals obtained from the cross P18 (H82.337/49) × P40 (H80.696/4) (Gebhardt et al. 1991, 2003; Leister et al. 1996).

\section{Preparation of high-molecular-weight (HMW) DNA}

High-molecular-weight DNA was prepared from PD59 protoplasts. Leaves were cut into thin slices with a sterile razor blade and incubated in $100 \mathrm{ml}$ in Protoplast Enzyme Solution [containing per $100 \mathrm{ml}: 450 \mathrm{mg}$ MS salts, $13.7 \mathrm{~g}$ sucrose, $10 \mathrm{mg}$ inositol, $25 \mathrm{mg}$ xylose, $0,1 \mathrm{ml}$ MS vitamins, $100 \mathrm{mg}$ cellulase R10 (Sigma-Aldrich, St. Louis, USA), $500 \mathrm{mg}$ macerozym R10 (Serva, Heidelberg, Germany), pH 5.6] overnight at $28^{\circ} \mathrm{C}$ in the dark. Leaf debris was removed, first by filtering the protoplast suspension through a stainless steel sieve $(50-\mu \mathrm{m}$ mesh) and then by centrifugation at $800 \mathrm{rpm}$ for $5 \mathrm{~min}$ at $4^{\circ} \mathrm{C}$. The cells floating on top were transferred to a new tube filled with W5 buffer $\left(154 \mathrm{mM} \mathrm{NaCl}, 125 \mathrm{mM} \mathrm{CaCl}_{2}, 5 \mathrm{mM} \mathrm{KCl}, 5 \mathrm{mM}\right.$ glucose, $\mathrm{pH}$ 5.6-6.0) and centrifuged at $500 \mathrm{rpm}$ for $5 \mathrm{~min}$ at $4^{\circ} \mathrm{C}$. The protoplasts were then checked under the microscope and resuspended in a suitable volume of $\mathrm{MaMg}$ buffer (450 mM mannitol, $15 \mathrm{mM} \mathrm{MgCl}_{2}$, $5 \mathrm{mM}$ MES, $\mathrm{pH}$ 5.5-6.7) to a concentration of $2 \times 10^{7}$ protoplasts $/ \mathrm{ml}$. The cells were mixed with an equal volume of $1 \%$ low-melting-point agarose (Epicentre) dissolved in $\mathrm{MaMg}$ buffer, and aliquoted into plug molds (Bio-Rad). Plugs were washed according to Choi and Wing (http://www.genome.clemson.edu/protocols) and stored in TE buffer $(10 \mathrm{mM}$ Tris- $\mathrm{HCl}, 1 \mathrm{mM}$ EDTA, $\mathrm{pH} 8.0)$ at $4^{\circ} \mathrm{C}$.

\section{Plasmid vector preparation}

pCLD04541 (Jones et al. 1992) was isolated using a Plasmid Maxi Kit (Qiagen) and further purified by two rounds of cesium chloride gradient centrifugation (Sambrook et al. 1989). After complete digestion with HindIII, the plasmid was extracted with phenol/chloroform, resuspended in TE and stored at $-20^{\circ} \mathrm{C}$. Prior to ligation, the vector was dephosphorylated with shrimp phosphatase (Roche Diagnostics) by incubating $500 \mathrm{ng}$ of plasmid with $1 \mathrm{U}$ of the enzyme at $37^{\circ} \mathrm{C}$ for $1 \mathrm{~h}$. The enzyme was then inactivated by incubation at $65^{\circ} \mathrm{C}$ for $30 \mathrm{~min}$. 


\section{Library construction and characterization}

Individual plugs were sliced into eight pieces and incubated for $1 \mathrm{~h}$ on ice in a total volume of $150 \mu \mathrm{l}$ of restriction enzyme buffer $(10 \mathrm{mM}$ Tris- $\mathrm{HCl}, 100 \mathrm{mM}$ $\mathrm{NaCl}, 5 \mathrm{mM} \mathrm{MgCl} 2,1 \mathrm{mM} \beta$-mercaptoethanol, $\mathrm{pH}$ 8.0) containing $0.1 \mathrm{mg} / \mathrm{ml} \mathrm{BSA}$ and $1.6 \mathrm{mM}$ spermidine. After adding $6 \mathrm{U}$ of HindIII, the reaction was further incubated on ice for $10 \mathrm{~min}$. After digestion at $37^{\circ} \mathrm{C}$ for $20 \mathrm{~min}$, the reaction was placed on ice, and a $1 / 10$ th volume of $0.5 \mathrm{M}$ EDTA $(\mathrm{pH} 8.0)$ was added to inhibit the enzyme. The agarose pieces were loaded onto a $1 \%$ low melting point agarose gel in $0.5 \times \mathrm{TBE}$. Lambda ladder PFGE (New England Biolabs) was used as a size marker. Pulsed field gel electrophoresis (PFGE) was performed in a CHEF-DR III (Bio-Rad) using the following settings: initial switching time $60 \mathrm{~s}$, final switching time $90 \mathrm{~s}$, voltage gradient $6 \mathrm{~V} / \mathrm{cm}$, angle $120^{\circ}$, running time $19 \mathrm{~h}$ at $14^{\circ} \mathrm{C}$. After electrophoresis, the gel piece containing the size ladder and $0.5 \mathrm{~cm}$ of digested HMW DNA was stained with ethidium bromide and visualized under UV light. Stained and unstained gel pieces were aligned side by side and fragments in the $100-500 \mathrm{~kb}$ range were cut from the unstained gel. Gel slices containing different DNA size fractions (fraction 1: $250-300 \mathrm{~kb}$, fraction $2: 150-250 \mathrm{~kb}$, fraction $3: 100$ $150 \mathrm{~kb})$ were collected separately. The gel slices were incubated with gelase (Epicentre) following the supplier's instructions, except that the concentration of $\mathrm{NaCl}$ in $1 \times$ gelase buffer was increased to $100 \mathrm{mM}$ to improve the recovery of DNA fragments larger than $100 \mathrm{~kb}$. Aliquots $(100 \mathrm{ng})$ of partially restricted, sizeselected DNA were ligated to the same amount of HindIII-restricted and dephosphorylated pCLD04541 vector in $110 \mu \mathrm{l}$ of $50 \mathrm{mM}$ Tris- $\mathrm{HCl}(\mathrm{pH} 7.6), 10 \mathrm{mM}$ $\mathrm{MgCl}_{2}, 1 \mathrm{mM}$ ATP, $1 \mathrm{mM}$ DTT, 5\% (w/v) polyethylene glycol-8000, containing $6 \mathrm{U}$ of T4 DNA ligase (Life Technologies). Ligations were incubated at $16^{\circ} \mathrm{C}$ for at least $24 \mathrm{~h}$. After ligation, salts were removed by dialysis against $0.1 \times$ TE using 30,000 NW filters (Millipore). For transformation, $1 \mu \mathrm{l}$ of ligation reaction was mixed with $25 \mu \mathrm{l}$ of transformation-competent DH10B Escherichia coli cells (Life Technologies) and transformed by electroporation using a Gene Pulser (Bio-Rad). The electroporator settings used were: capacitance $25 \mu \mathrm{F}$, voltage $1.8 \mathrm{kV}$, resistance $100 \Omega$. Transformed cells were recovered in $600 \mu \mathrm{l}$ of SOC medium $(2 \%$ Bacto tryptone, $0.5 \%$ Bacto yeast extract, $10 \mathrm{mM} \mathrm{NaCl}, 2.5 \mathrm{mM}$ $\mathrm{KCl}, 20 \mathrm{mM} \mathrm{MgSO} / \mathrm{MgCl}_{2}$ and $20 \mathrm{mM}$ glucose), incubated at $37^{\circ} \mathrm{C}$ for $50 \mathrm{~min}$ and plated on $\mathrm{LB}$ medium containing tetracycline $(15 \mathrm{mg} / \mathrm{l})$, IPTG $(14 \mathrm{mg} / \mathrm{l})$ and $\mathrm{X}$-gal $(60 \mathrm{mg} / \mathrm{l})$. After incubation for $24 \mathrm{~h}$, recombinant clones were picked and checked for insert size (see below). Ligation mixtures with acceptable insert size and transformation efficiency were used to construct the library. Multiple transformations were carried out and plated on $22 \times 22 \mathrm{~cm}$ plates. Recombinant clones were picked using a Q-Pix robot (Genetix) and inoculated into 384-well plates prefilled with LB freezing medium
(Sambrook et al. 1989). Replicas were made from each 384-well plate using a BioGrid robot (BioRobotics) and stored at $-70^{\circ} \mathrm{C}$. Plasmid DNA was isolated from 90 randomly picked BAC clones by alkaline lysis (Sambrook et al. 1989). The inserts were released by digestion with NotI, and their sizes were determined by PFGE on $1 \%$ agarose (initial switching time $5 \mathrm{~s}$, final switching time $15 \mathrm{~s}$, potential gradient $6 \mathrm{~V} / \mathrm{cm}$ angle $120^{\circ}$, running time $16 \mathrm{~h}$ at $\left.14^{\circ} \mathrm{C}\right)$.

\section{Library screens}

High-density colony filters were prepared from the BAC library using the BioGrid robot. In all, 27,648 independent clones were double-spotted onto Pall membranes (Biodyne) in a $5 \times 5$ pattern. The filters were processed according to Sambrook et al. (1989). The probes were labeled with $\left[\alpha-{ }^{32} \mathrm{P}\right] \mathrm{dCTP}$ using the random priming method (Feinberg and Vogelstein 1984). Filter hybridization and determination of BAC position was performed as described previously (Gebhardt et al. 1989; Ballvora et al. 2002). The library was screened with labeled probes for the following defence-response genes: a cDNA (NtPR-5) from tobacco encoding the pathogenesis related gene PR-5, provided by John Ryals (Payne et al. 1988); a cDNA (PAL) from potato encoding phenylalanine ammonia-lyase, provided by Erich Kombrink (Fritzemeier et al. 1987), and potato osmotinlike genes. Primers for osmotin-like genes (Table 1) were designed on the basis of the consensus sequence of the GenBank accessions X65701, S40046, X61679, AF093743, X72927, X72928, X67244 and M21346. A $700-b p$ PCR product was amplified and used as the probe.

\section{Construction of BAC subclones}

DNA fragments obtained by digestion of BACs $(1 \mu \mathrm{g}$ of BAC plasmid DNA) with HindIII, XhoI, XhoI/NotI or EcoRV which showed homology to genes for osmotinlike or acidic PR-5 proteins were subcloned into pBluescript (Stratagene) after purification on Quiaquick columns (Qiagen), and transformed into DH10B cells using standard procedures (Sambrook et al. 1989). Osmotin subclones were identified with the osmotin primers (Table 1). Subclones harboring acidic PR-5 sequences were identified by PCR screening with E22 primers (Table 1). The E22 primers were designed based on sequence motifs conserved between the $\mathrm{T} 7$ end of BAC clone BB43d14 and GenBank accessions X15224 and $\times 15223$.

\section{Sequence analysis}

Plasmid DNA was isolated using the Plasmid Midi Kit (Qiagen). The BACs and subclones were end-sequenced 
Table 1 PCR-based markers and hybridization probes

\begin{tabular}{|c|c|c|c|c|}
\hline Probe and marker names & Forward (f) and reverse $(\mathrm{r})$ primers $\left(5^{\prime} \rightarrow 3^{\prime}\right)$ & $\mathrm{TA}^{\mathrm{a}}\left({ }^{\circ} \mathrm{C}\right)$ & Size (bp) & Marker type and enzyme ${ }^{\mathrm{b}}$ \\
\hline PR-5, E22 & GATGGTAGTGGCCGAGGCAAATG (f) & 56 & $400+500$ & SCAR \\
\hline PR-5, 321c & $\begin{array}{l}\text { CACACAACAATTACGATACTCCTTC (f) } \\
\text { GAGATGTCCTTAAACAGAGAGAGTAG (r) }\end{array}$ & 56 & 500 & CAPS; ApoI \\
\hline Osmotin & $\begin{array}{l}\text { GAGGTACGCAACACCTGTCCATAC (f) } \\
\text { AGGGGAAATTTGGGCTAGTAACAC (r) }\end{array}$ & 60 & 700 & - \\
\hline Contig B & $\begin{array}{l}\text { TGATGGTGCTGGTAGAGGTTCTTG (f) } \\
\text { AAGACCGATTGCCTGAAGCATTAG (r) }\end{array}$ & 58 & 700 & CAPS; AluI \\
\hline S. $p h u$ pA35 & $\begin{array}{l}\text { GAGAAAATGAGTCACTTGACAA (f) } \\
\text { TCAGATCTTAGCCACTTCAAGC (r) }\end{array}$ & 60 & 844 & CAPS; $M b o I$ \\
\hline
\end{tabular}

${ }^{\mathrm{a}}$ TA annealing temperature

${ }^{\mathrm{b}} C A P S$ Cleaved amplified polymorphic sequence; SCAR sequence-characterized amplified region

using T3 and T7 primers. Subclones were sequenced by primer walking. Custom sequencing was performed by the ADIS unit at the Max Planck Institute for Plant Breeding Research, using the ABI PRISM Dye Terminator Cycle Sequencing Ready Reaction Kit and an AB377 automated DNA Sequencer (PE Biosystems). DNA sequence analysis was performed using the Wisconsin Package, version 10.0 (Genetics Computer Group). The programs BLASTN and BLASTX from NCBI were used to search for sequence homology. Sequences of the subclones were assembled and analyzed using Jellyfish 1.3 (Bioware). SignalP software (http:// www.cbs.dtu.dk/services/SignalP) was used to predict signal sequences. The sequence alignment for the phylogenetic tree was performed with the Wisconsin Package, and the phylogram was constructed with the program TreeTop-Phylogenetic Tree Prediction, provided by Genebee (http://www.genebee.msu.su/services/ phtree_reduced.html).

\section{Determination of the parental origin of BACs}

Amplicons were generated with the same primers from 'haploid' BAC plasmid DNA and from genomic DNAs of the S. phureja and S. tuberosum parents of PD59, based on BAC end or internal sequence information. The amplicons were sequenced and the sequences were aligned. Single nucleotide polymorphisms (SNPs) that discriminated between the parents were used to determine the parental origin of BACs, based on the SNP allele present in the BAC sequence.

PCR-based markers and linkage mapping

Genomic DNA templates ( $25 \mathrm{ng}$ ) were amplified in $25 \mu \mathrm{l}$ of PCR buffer (20 mM Tris- $\mathrm{HCl} \mathrm{pH} \mathrm{8.4,50} \mathrm{mM} \mathrm{KCl),}$ $200 \mu \mathrm{M}$ dNTPs, $2.5 \mathrm{mM} \mathrm{MgCl}_{2}$, containing $0.3 \mathrm{pmol}$ of each primer (Table 1) and $2 \mathrm{U}$ of Taq polymerase (Life Technologies). Cycle parameters were as follows: $96^{\circ} \mathrm{C}$ for $5 \mathrm{~min}$, followed by 30 cycles of $94^{\circ} \mathrm{C}$ for $20 \mathrm{~s}, 56-$ $60^{\circ} \mathrm{C}$ (see Table 1 for precise annealing temperatures) for $30 \mathrm{~s}$ and $72^{\circ} \mathrm{C}$ for $1 \mathrm{~min}$, and a final extension cycle at $72^{\circ} \mathrm{C}$ for $6 \mathrm{~min}$. Segregating PCR fragments were scored as present or absent in the diploid mapping populations F1840 (Gebhardt et al. 2003) or PD (Ghislain et al. 2001). The fragments were mapped relative to the existing marker framework databases using the software package MAPRF (Ritter et al. 1990) or MAPMAKER/EXP v3.0b.

\section{Results}

BAC library construction and characterization

A BAC library of about 50,000 clones was constructed from HMW DNA of the diploid, interspecific hybrid clone PD59. After partial digestion with HindIII and size-fractionation by PFGE, ligations of three DNA size fractions $(250-300,150-250$, and $100-150 \mathrm{~kb})$ were used for transformation, and the average insert size of random clones was assessed by PFGE after digestion with $N o t \mathrm{I}$. The largest average insert size of around $80 \mathrm{~kb}$ was obtained with fraction 3 , which contained DNA fragments in the size range from $100 \mathrm{~kb}$ to $150 \mathrm{~kb}$. Slight differences in DNA concentration influence mobility during PFGE electrophoresis, such that the DNA size marker does not always provide an exact indication of fragment size. Similar results have been obtained by others (Vinatzer et al. 1998; Allouis et al. 2001; Ming et al. 2001). Cloning of the larger sized fractions resulted in smaller sized inserts, most probably, due to the preferential transformation of smaller DNA fragments that were trapped in these fractions during PFGE (Woo et al. 1994; Zhang et al. 1995; 


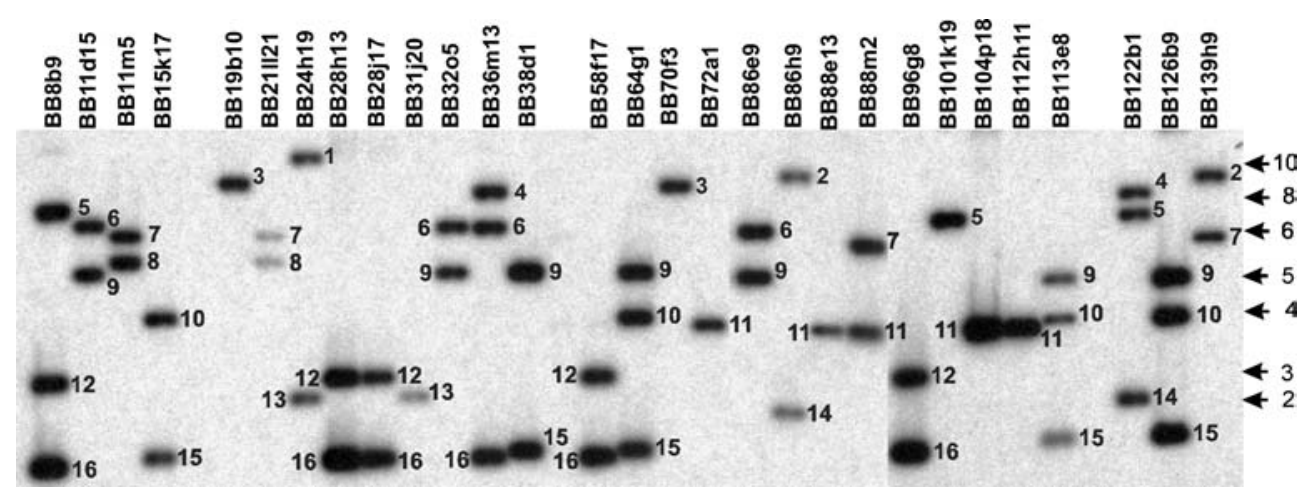

Fig. 1 Southern analysis of 29 BACs with a potato PAL cDNA probe. Plasmid DNA was digested with HindIII. Positions of size markers (sizes in $\mathrm{kb}$ ) are indicated by the arrows on the right. The different HindIII fragments are numbered from 1 to 16 . The

Fritjers et al. 1997). The library constructed with DNA from fraction 3, with an average insert size of $80 \mathrm{~kb}$, was used for all subsequent analyses. Based on a potato haploid genome size of $\sim 850 \mathrm{Mb}$ (Arumuganathan and Earle 1991) and an average insert size of $80 \mathrm{~kb}$, the 50,000 clones in this library represent 4.7 genome equivalents. Due to the interspecific nature of PD59, the BAC library actually represented around 2.3 genome equivalents each of the $S$. tuberosum and $S$. phureja genomes.

Genomic organization of $P A L$ genes

Screening of high-density colony filters of the entire BAC library with a potato phenylalanine ammonia-lyase $(P A L)$ probe identified 29 cross-hybridizing clones. Southern analysis of the HindIII restricted BAC plasmids revealed at least 16 different cross-hybridizing restriction fragments in the size range between $1 \mathrm{~kb}$ and $10 \mathrm{~kb}$ (Fig. 1). Assuming that each restriction fragment corresponds to at least one gene copy, 16 PAL genes, including orthologous genes from $S$. tuberosum and $S$. phureja, are represented in the BAC library. The true gene number might be lower due to the presence of internal HindIII restriction sites or higher if more than one gene copy is present per restriction fragment. The frequency of individual restriction fragments in the 29 BACs was between one and six, with an average of 3.4 (1.7 for each parent), indicating a lower redundancy (genome coverage) of the library than was estimated based on genome size, average insert size and clone number (see above). Seventeen different, partially overlapping fragment patterns were distinguished among the 29 BACs, of which fourteen were composed of two or three restriction fragments (Fig. 1). This shows that potato PAL is encoded by a multigene family, and that members of the family are often closely linked in the genome.
Genomic organization of acidic $P R$-5-homologous genes

Screening of the entire BAC library with the tobacco cDNA probe NtPR-5 (Accession No. X12739; Payne et al. 1988; Ward et al. 1991) identified a single, $45-\mathrm{kb}$ BAC clone (BB43d14). A Southern gel blot bearing HindIIIrestricted DNA of PD59 and BB43d14 was probed with NtPR-5 (Fig. 2). The three major cross-hybridizing fragments detected in PD59 were all present in BB43d14, suggesting that most, if not all, potato $P R-5$ homologues were included in this BAC. Sequencing of both ends of the BB43d14 insertion revealed one end with 89 and $81 \%$ sequence identity to the tobacco genes E22 (X15224) and E2 (X15223), respectively. E22 and E2 encode the major and minor forms, respectively, of PR-S $(=\mathrm{PR}-\mathrm{R}=\mathrm{NtPR}-5)$ from Nicotiana tabacum (Van Kan et al. 1989). EcoRV, XhoI and XhoI-NotI restriction fragments of BAC BB43d14 containing PR-5 homologous sequences were subcloned and partially sequenced. Four different PR-5-homologous ORFs were found in subclones $319(7 \mathrm{~kb}), 321(7 \mathrm{~kb})$ and $21(4 \mathrm{~kb})$. ORFs PR-5/319 (227 amino acids; GenBank Accession No.

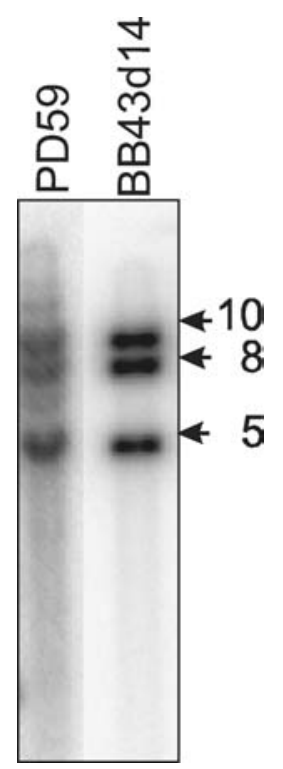

Fig. 2 Southern analysis of plant PD59 and BAC clone BB43d14 with the NtPR-5 cDNA probe. DNA was restricted with HindIII. The positions of size markers are shown on the right 
AY737315) and PR-5/21 (229 amino acids; AY737316) were $3 \mathrm{~kb}$ apart, whereas, ORFs PR-5/321c (246 amino acids; AY737317) and PR-5/321d (221 amino acids; AY737317) were tandemly duplicated without any intervening sequence. ORF PR-5/321d was shorter due to the apparent lack of the expected N-terminal sequence (Fig. 3). BB43d14, and therefore, all PR-5 ORFs, originated from the tuberosum parent of PD59. Like other PR-5 genes (Velzhahan et al. 1999), the four ORFs did not have introns. The three apparently complete ORFs included a putative signal peptide of 21-25 amino acids at the $\mathrm{N}$-terminus. The physical distance of PR-5/321c and PR-5/321d from ORFs PR-5/319 and PR-5/21 was not determined. The alignment of the deduced amino acid sequences of the four ORFs (Fig. 3) shows that the conserved regions of the proteins include 16 cysteine residues.

The position of the acidic $P R$-5-homologous genes on potato chromosome XII (Fig. 4; Gebhardt et al. 2001) was confirmed by mapping a 500-bp PCR product obtained with E22 primers (Table 1), which segregated in the F1840 population. To map the $P R-5$ locus in the PD population, two CAPS markers (PR-5/319, PR-5/321c, Table 1) were developed based on single nucleotide polymorphisms (SNPs) between the alleles present in the $S$. phureja parent of the PD population, which was heterozygous in the putative promoter region of genes $P R-5 / 319$ and $P R-5 / 321 c$ (not shown). Both markers mapped to linkage group XII of the $S$. phureja parent (not shown). This map position does not overlap with that of the late blight QTL on linkage group XII of the
S. phureja parent (Ghislain et al. 2001). Due to apparently high homozygosity at the $P R-5$ locus in the $S$. tuberosum parent, we could not assess whether the $P R-5$ locus overlaps with the late blight QTL on linkage group XII of the $S$. tuberosum parent.

Genomic organization of basic $P R-5$ (osmotin-like)homologous genes

Screening of the BAC library with an osmotin probe identified six positive BACs: BB18h19 (85 kb), BB41d14 (65 kb), BB48h15 (90 kb), BB82a11 (70 kb), BB86e10 $(100 \mathrm{~kb})$ and BB99n12 (35 kb). Comparison of HindIII restricted DNAs of PD59 with the BACs on the Southern blots hybridized to the osmotin probe showed that all gene copies present in PD59, with the exception of two weakly cross-hybridizing genomic fragments, were accounted for in the six BACs, (Fig. 5a). Sequencing of the BAC ends revealed $94 \%$ sequence identity between the T3 end of BB41d14 and an osmotin-like gene of $S$. commersonii (X72927). PCR primers were designed from the BAC insertion ends in order to detect overlaps and orient overlapping BACs relative to each other. This resulted in the assembly of two contigs of approximately $100 \mathrm{~kb}(\mathrm{~A})$ and $120 \mathrm{~kb}$ (B), respectively (Fig. 5b). Comparative sequence analysis of the amplicons from BACs and parental lines confirmed the overlaps and determined the origin of each BAC from one or other of the parents of the PD population. Eight genomic HindIII fragments were distinguished and
Fig. 3 Alignment of amino acid sequences deduced from $P R-5$ homologous genes located on BB43d14. ORFs PR-5/21, PR$5 / 319$ and PR-5/321c are complete. ORF PR-5/321d lacks the N-terminal region when compared to the other genes, and is fused to the stop codon of ORF PR-5/321c. Amino acids conserved in all genes are shaded. The 16 cysteine residues conserved in all PR-5 proteins are indicated by inverted filled triangle, and stop codons by asterisks. The most likely site of cleavage of the putative signal peptide is indicated by a vertical line

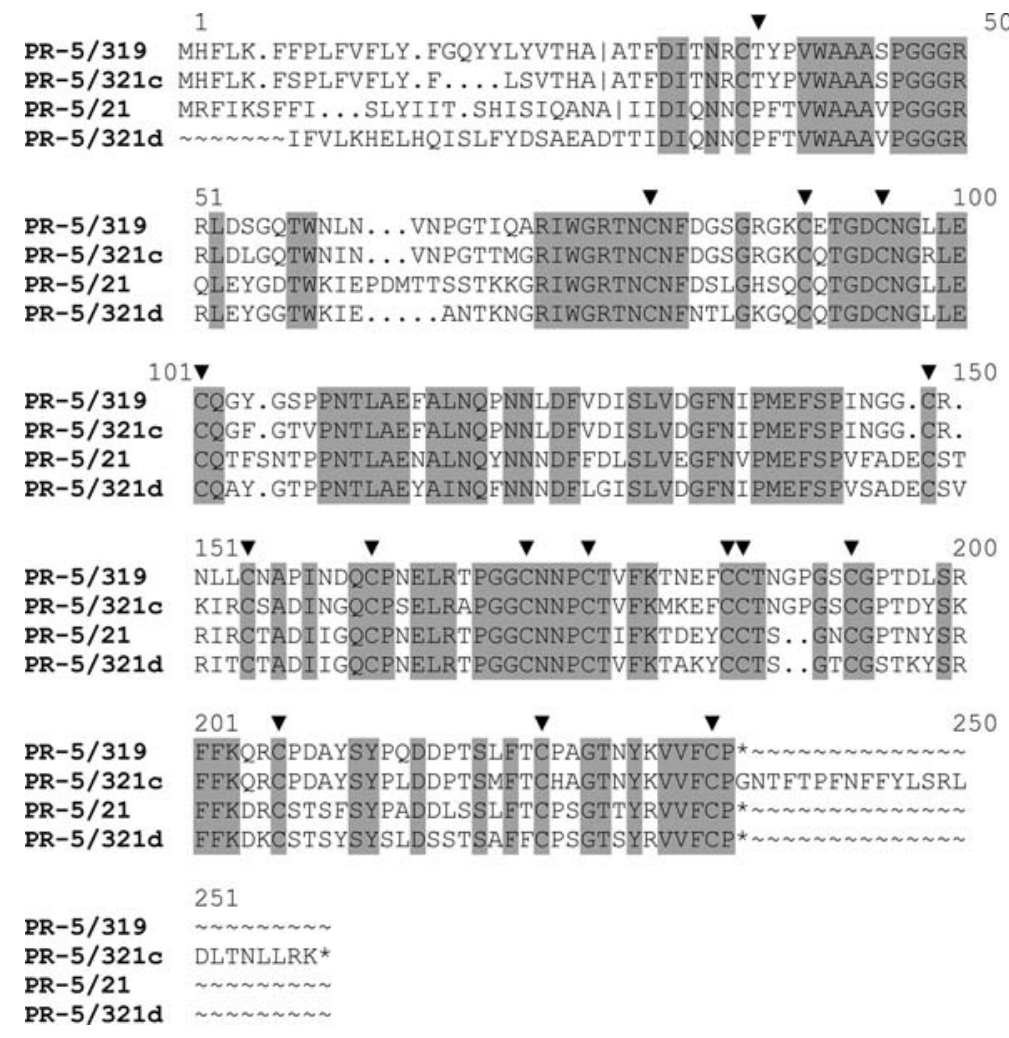



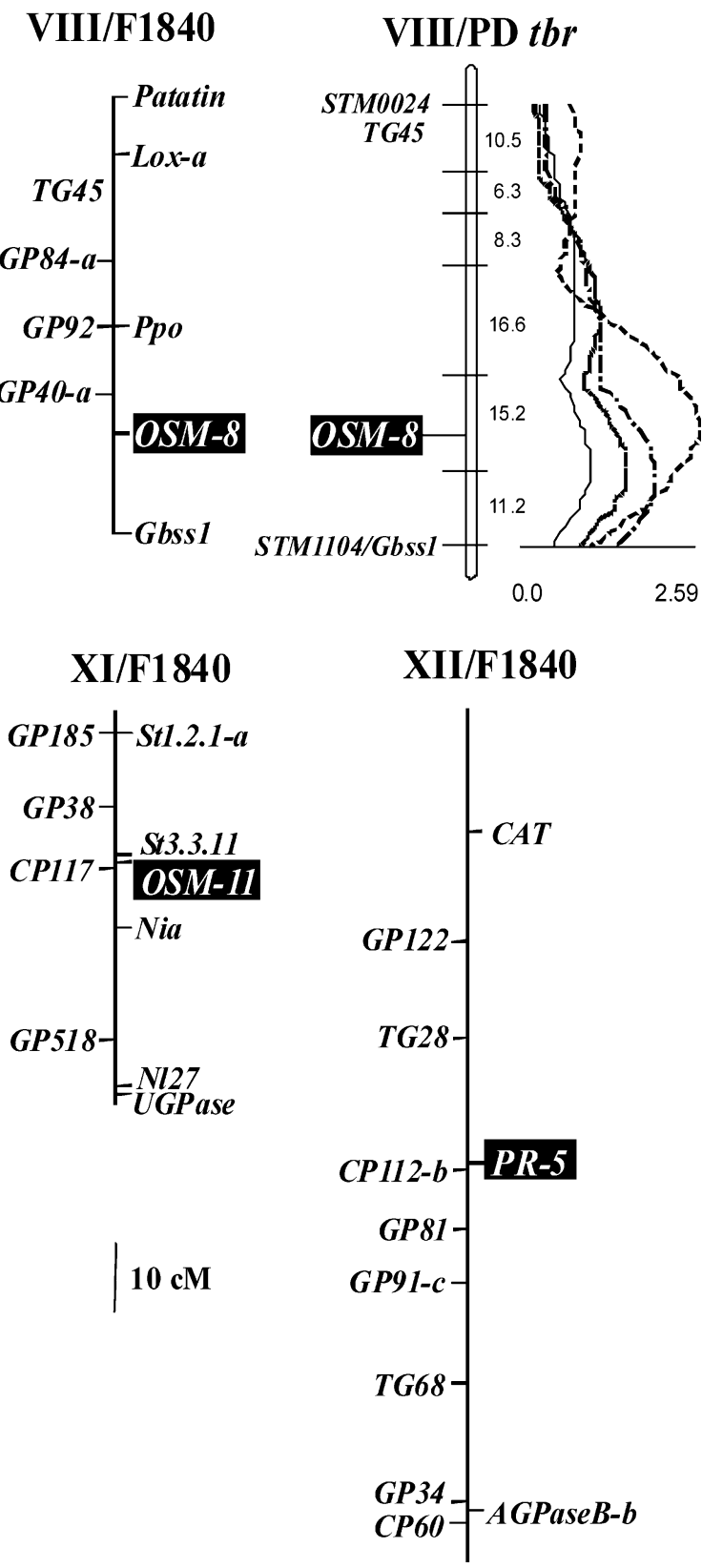

numbered from one to eight (Fig. 5a). Based on the presence or absence in the overlapping BACs, the approximate positions of the eight HindIII fragments in the contigs were deduced (Fig. 5b). HindIII fragments 1 (7.2 kb, GenBank Accession No. AY737312) and 2 (5.7 kb, AY737313) of BB18h19, HindIII fragments 3 (8 kb), 4 (5.8 kb, AY737311) and $5(3.4 \mathrm{~kb})$ of BB48h15 and HindIII fragment 8 (6.8 kb, AY737314) of BB82a11 were subcloned and sequenced. HindIII fragments 5 and 3 were adjacent to each other (Accession No. AY737310). This was confirmed by sequencing an amplicon from BB48h15, which spanned the adjacent ends of the subclones bearing HindIII fragments 3 and 5 (Fig. 5b). Comparison of the sequences of the subclones with the databases revealed nine osmotin-like ORFs
Fig. 4 Positions of $P R-5$ and $O S M$ loci on potato molecular maps. Linkage groups VIII, XI and XII of the F1840 mapping population are shown, together with a subset of the RFLP loci that have been mapped to each (http://gabi.rzpd.de/PoMaMo.html). RFLP loci identified by functional gene probes are shown to the right of the linkage groups. The suffixes $-a,-b$ and $-c$ indicate that more than one RFLP locus was detected with the same marker probe. Lox lipoxygenase; Ppo polyphenol oxidase; Gbss 1 granule-bound starch synthase 1: St1.2.1, St3.3.11 resistance-gene-like sequences; Nia nitrate reductase; Nl27 N-resistance-gene-like sequence; UGPase UDP-glucose pyrophosphorylase; $C A T$ catalase; AGPase B ADPglucose pyrophosphorylase B. Linkage group VIII of the $S$. tuberosum parent of mapping population PD was adapted from Ghislain et al. (2001) and is based on AFLP (names not shown) and microsatellite (STM****) markers. STM1104 is a microsatellite within the noncoding region of the Gbss 1 gene (Milbourne et al. 1998). Marker loci TG45, OSM-8 and Gbss 1 are shared between the two molecular maps of potato chromosome VIII. LOD curves for a late blight QTL on linkage group VIII of the S. tuberosum parent of population PD (Ghislain et al. 2001) are shown to the right of the linkage group

without apparent introns: OSM-5a, OSM-3b, OSM-3f, OSM-3c, OSM-4d, OSM-1g, OSM-1h and OSM-2d in contig A, and OSM-8e in contig B (Fig. 5b). The ORFs OSM-2d and OSM-4d (derived from $S$. tuberosum and $S$. phureja, respectively) were most similar to each other $(97.7 \%$ at the nucleotide and $99.2 \%$ at the amino acid sequence level). Upstream and downstream sequences were also highly similar $(97.2$ and $94.8 \%$ identity, respectively). This suggested that $O S M-2 d$ (S. tuberosum) and $O S M-4 d$ (S. phureja) are orthologous genes (Fig. 5b). The alignment of the deduced amino acid sequences is shown in Fig. 6. The eight osmotin-like genes in contig A encoded proteins of between 226 and 250 amino acids (OSM-2d, OSM-4d and OSM-3c: 250 amino acids, OSM-1h and OSM-1g: 226 amino acids, OSM-3f: 246 amino acids, OSM- 3b and OSM-5a: 247 amino acids), which all had the 16 cysteine residues that are highly conserved in the PR-5 family, and shared more than $90 \%$ similarity with other osmotin-like genes. The single osmotin-like gene present in contig B encodes a shorter polypeptide of 220 amino acids (OSM-8e). An internal 10-amino acid deletion included cysteine residues 11 and 12. Signal peptides of 21-26 amino acids length were predicted for the osmotin-like proteins in contigs $\mathrm{A}$ and $\mathrm{B}$.

The CAPS markers specifically developed for contigs A and B (Table 1, Fig. 5b) segregated in the F1840 mapping population and identified two loci, $O S M-8$ and $O S M-11$, on linkage groups VIII and XI, respectively (Fig. 4). A further PCR marker was designed for the osmotin-like gene pA35 of $S$. phureja (Accession No. AY743928) (Table 1), which is most closely related to OSM-2d, OSM-3c and OSM-4d (Fig. 7, see below) located within contig A on chromosome VIII. This marker segregated in population PD (Ghislain et al. 2001) and identified the same $O S M-8$ locus (Fig. 4). $O S M-8$ on chromosome VIII of the $S$. tuberosum parent of the PD population was linked to a QTL for late blight resistance (Fig. 4). 
Fig. 5 a, b Genomic organization of osmotin-like genes. a Southern analysis of plant PD59 and six BACs selected with the osmotin-like probe. DNA was digested with HindIII. The different HindIII restriction fragments are numbered from one to eight and their sizes $(\mathrm{kb})$ are indicated on the right. b Contig A and Contig B based on four and two overlapping BACs, respectively. The relative and approximate positions of eight HindIII restriction fragments in contigs $\mathrm{A}$ and $\mathrm{B}$ are shown, and the sequenced subclones are indicated by the corresponding fragment numbers. Nine osmotin-like genes $(O S M)$ were identified by sequencing the subcloned HindIII fragments 1 , 2, 3, 4, 5 and 8. OSM genes of $S$. phureja and $S$. tuberosum are indicated as black and white boxes, respectively. Inferred $O S M$ genes that were not sequenced are shown as grey boxes. The arrows indicate the positions of the CAPS markers (Table 1) used to map contigs A and $\mathrm{B}$
A
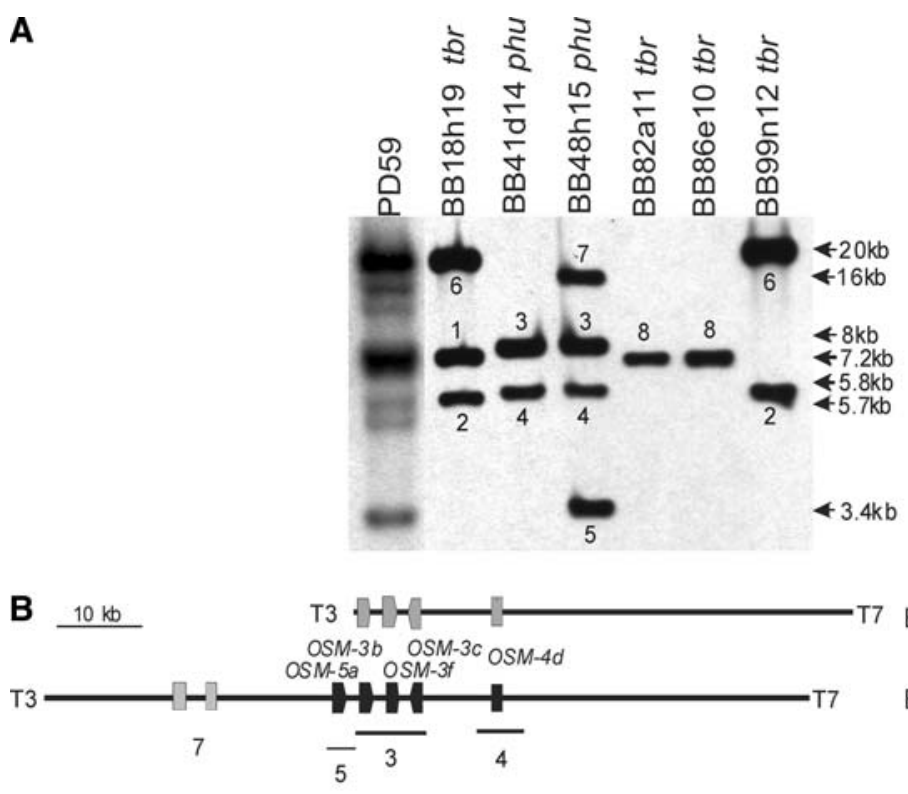

BB41 d14phu (65kb)

BB48h15phu (90kb)

Contig A

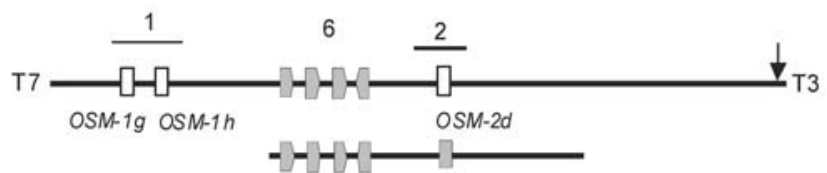

BB18h19tbr (85kb) BB $99 \mathrm{n} 12 \mathrm{tbr}(35 \mathrm{~kb})$ OSM-8

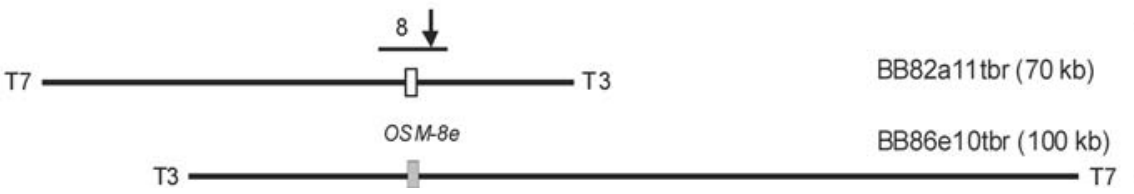

Phylogenetic tree of acidic and basic PR-5 polypeptides in solanaceous species

A phylogenetic tree was constructed based on the deduced, full-length sequences of acidic PR-5 and basic PR-5-like (osmotin-like) polypeptides from $S$. phureja and $S$. tuberosum, homologues from other solanaceous species, and the two most closely related acidic PR-5 homologues from Arabidopsis thaliana (Fig. 7). The polypeptides from solanaceous species were clearly separated from those of Arabidopsis, and formed four major clusters. Cluster I included acidic PR-5 proteins from $S$. tuberosum and Nicotiana tabacum. Cluster II included osmotin-like proteins OSM3c, OSM-2d, OSM-4d and homologues from S. lycopersicum (tomato), S. commersonii, S. phureja and $N$. sylvestris. Cluster III included OSM-3b, OSM-3f, OSM-5a, homologues from other Solanum species $(S$. commersonii, S. lycopersicum, S. nigrum, $S$. dulcamara) and from Capsicum annum, Petunia hybrida and $N$. tabacum. Cluster IV was new and consisted of osmotin-like proteins OSM-1h, OSM-1g (both encoded on chromosome VIII) and OSM-8e (encoded on chromosome XI). The protein encoded by $P R-5 / 21$ was separated from all four clusters and formed a unique branch.

\section{Discussion}

Large insert libraries of tuber-bearing Solanum species

We have constructed a BAC library from an interspecific hybrid between $S$. tuberosum and $S$. phureja, which are both cultivated potato species. Other BAC libraries have been constructed for different $S$. tuberosum genotypes (Kanyuka et al. 1999; Ballvora et al. 2002) and for the wild potato species S. bulbocastanum (Song et al. 2000; Vander Vossen et al. 2003). Together with large-insert libraries for the highly colinear genome of tomato, Solanum lycopersicum (Martin et al. 1992; Bonnema et al. 1996; Hamilton et al. 1999; Budiman et al. 2000), these represent a unique resource for comparative genome analysis at the intra- and interspecific level in the Solanaceae family. High-density colony filters of the library can be screened by hybridization with homologous probes to isolate full-length genomic clones in a single step. With an average insertion size of $80 \mathrm{~kb}$, the library is also suitable for investigating the organization of gene families in physically linked clusters. The analysis of the $O S M-8$ locus showed that orthologous genomic regions from $S$. tuberosum and $S$. phureja can be identified, which may then be tested for quantitative 
Fig. 6 Alignment of amino acid sequences deduced from nine osmotin-like genes located on BB48h15 (S. phureja), BB18h19 (S. tuberosum) and BB82a11 ( $S$. tuberosum). Amino acids conserved in all genes are shaded. The 16 cysteine residues conserved in all OSM proteins are indicated by inverted filled triangle, and stop codons are indicated by asterisks. The most likely site for cleavage of the putative signal peptide is indicated by the vertical line
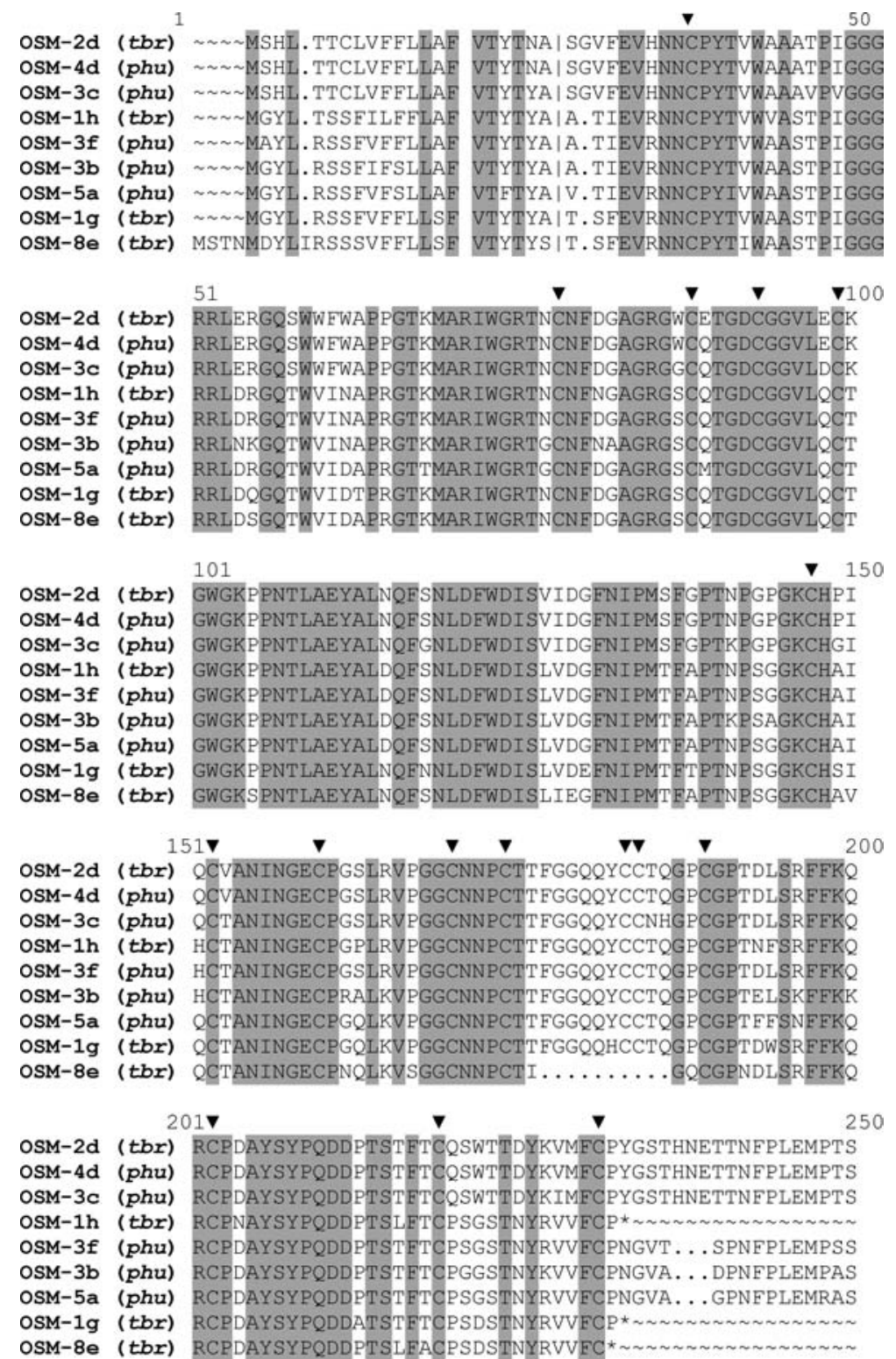

251

OSM-2d (tbr) TLELA*

OSM-4d (phu) TLEVA

OSM-3c (phu) ILEVA*

OSM-1h (tbr)

OSM-3f (phu) DEEAK

OSM-3b (phu) TDEVAK*

OSM-5a (phu) TDEVAK *

OSM-1g (tbr)

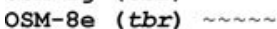

complementation by ballistic transformation of whole BAC DNA (Ercolano et al. 2004).

Genomic organization of defence-response genes

Three defence-response genes were studied by Southern analysis of selected BACs, sequencing and genetic mapping. All three genes are members of multigene families, which are clustered at one or more loci in the potato genome. The $P A L$ family was the most complex. The dihaploid potato genome was estimated to contain 40-50 PAL genes, based on copy number titration (Joos and Hahlbrock 1992), which corresponds to 20-25 gene copies per haploid genome. Our estimate of around 16 copies (based on the number of different HindIII restriction fragments present in 29 BACs) is somewhat lower. This difference may reflect the imprecision of both methods for estimating gene copy number, or it may be due to incomplete representation of $P A L$ genes 


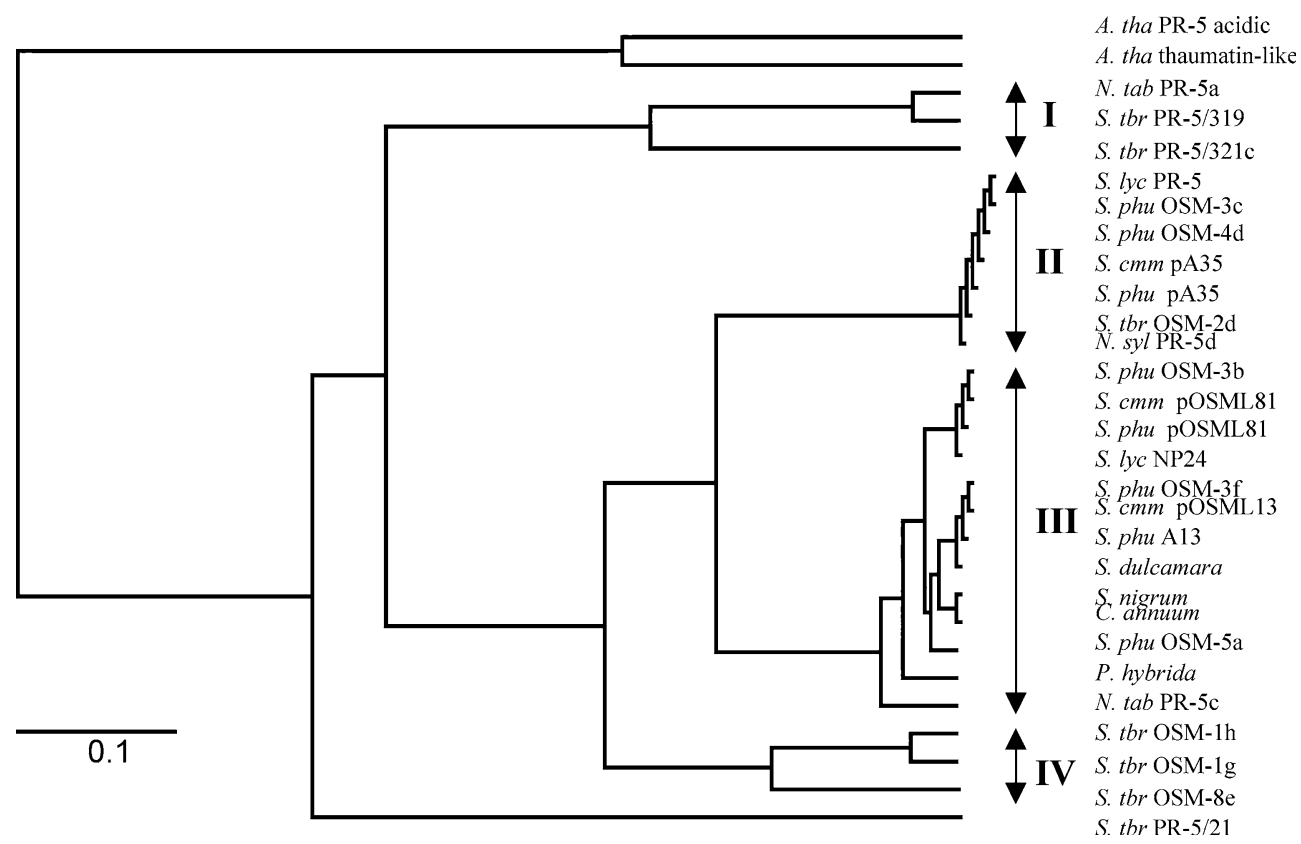

Fig. 7 Phylogenetic tree (GeneBee) constructed on the basis of the amino acid sequences deduced from three full-length $P R-5$ homologous genes of Solanum tuberosum and nine osmotin-like genes of $S$. tuberosum or $S$. phureja described in this paper, and homologues from other plants. A. tha PR-5 acidic and $A$. tha thaumatin-like: Arabidopsis thaliana GenBank Accessions M90510 and U83490. N. tab PR-5a and N. tab PR-5c: Nicotiana tabacum GenBank accessions X12739 and S30157. N. syl PR-5d: Nicotiana sylvestris GenBank accession D76437. S. lyc PR-5 and S. lyc NP24 : Solanum lycopersicum GenBank accessions AJ277064 and AF093743. S. $\mathrm{cmm}$ pA35, S. $\mathrm{cmm}$ pOSML81 and $S . \mathrm{cmm}$ pOSML13: Solanum commersonii GenBank accessions X67244, X72927 and X72928. S. phu A13, S. phu pA35 and S. phu pOSML81: Solanum phureja GenBank accessions AY743928, AY743929 and AY 743930. Solanum dulcamara GenBank accession AY007309, Solanum nigrum GenBank accession AAL87640, Capsicum annuum GenBank accession AF297646, Petunia hybrida GenBank accession AF376058

in the BAC library. RFLP mapping in various populations has identified six $P A L$ loci on potato chromosomes III, IX, X and XII (Gebhardt et al. 2001, https://gabi.rzpd.de/PoMaMo.html; Trognitz et al. 2002), some of which may contain clusters of two or more $P A L$ genes. This is indicated by the finding that most PAL BACs contained more than one genomic HindIII fragment. $P A L$ homologous loci on chromosomes III, IX and XII have been linked to QTLs for late blight resistance in potato (Leonards-Schippers et al. 1994; Trognitz et al. 2002). In Phaseolus vulgaris, a QTL for resistance to Colletotrichum lindemuthianum was also linked to $P A L$ genes (Geffroy et al. 2000). Anchoring of the PAL, BACs to the potato genetic map, sequencing and analysis of molecular and functional variability will give further insight into the structure of $P A L$ loci in the potato genome and their potential role in quantitative resistance.

Four homologues of genes for acidic PR-5 proteins were identified, all of which were located within a $45-\mathrm{kb}$ stretch on potato chromosome XII. The BAC clone carrying the four genes harbors all acidic $P R-5$ genes of this homology group in the potato genome. However, we cannot exclude the possibility that additional members of this gene family are present on this same BAC. Three of the sequenced genes were complete, whereas, the fourth gene $(P R-5 / 321 d)$ was truncated at the $5^{\prime}$ end and fused to the $3^{\prime}$ end of $P R-5 / 321 c$, which makes it unlikely that it is expressed. The amino acid sequence deduced from the complete gene $P R-5 / 319$ was $100 \%$ identical to the sequenced portion (58 $\mathrm{N}$-terminal amino acids) of the acidic thaumatin-like protein $\mathrm{C}$ that has been identified in intercellular fluids of potato plants during aging and after salicylate treatment (Pierpoint et al. 1990). Sequences of RT-PCR products generated from PD59 leaves all corresponded to $P R-5 / 319$ (R. Castillo-Ruiz, unpublished results). Thus $P R-5 / 319$ most probably encodes protein $\mathrm{C}$ and is probably secreted into the intercellular space in potato leaves. To the extent that it has been sequenced in PD59 and its parents, the $P R-5$ locus showed little polymorphism between the alleles. It was also not polymorphic in two tetraploid populations of $S$. tuberosum that were analyzed for late-blight QTLs (Bormann et al. 2004). Acidic $P R-5$ homologues also seem to be highly conserved in a range of solanaceous species (Castillo-Ruiz 2002). This limited genetic variation points to strong functional constraints on this gene family in the Solanaceae. Nine osmotin-like genes were found to be organized at two loci, eight genes in a 90-kb cluster on chromosome VIII and one single gene on chromosome XI. However, it cannot be excluded that additional copies are present on HindIII fragments 6 and 7, which were not sequenced (Fig. 5). These nine genes do not represent all osmotinlike genes of this homology group in the potato genome, as indicated by additional cross-hybridizing bands on genomic Southern blots of clone PD59. Three osmotinlike proteins and their corresponding genes have been 
characterized in the tuber-bearing wild species $S$. commersonnii (Zhu et al. 1995a, b). The S. commersonnii genes $O S M L 13$ and $O S M L 81$ were present in tandem orientation on the same Lambda genomic clone, like the $S$. phureja genes $O S M-3 b$ and $O S M-3 f$, which were located within a segment of $5 \mathrm{~kb}$ at the $O S M-8$ locus (Fig. 5). $O S M-3 b$ is most closely related to $O S M L 81$, whereas $O S M-3 f$ is most similar to $O S M L 13$ (Fig. 7). Thus, the $S$. commersonnii locus containing genes $O S M L 13$ and OSML81 is orthologous to the OSM-8 locus of $S$. phureja and $S$. tuberosum.

The branching topology of the phylogenetic tree suggests the following mode of evolution for the osmotin-like gene family. An ancestral gene appears to have undergone two rounds of duplication with subsequent divergence before speciation took place within the Solanaceae family. One of the four ancestral genes was then translocated to chromosome XI and evolved into OSM$8 e$, whereas, the other three genes remained in a cluster on chromosome VIII, and each of them has more recently undergone at least one more round of duplication.

Osmotin-like genes are functional candidates for quantitative resistance to late blight. Accumulation of osmotin-like proteins upon infection with $P$. infestans has been demonstrated in $S$. commersonnii (Zhu et al. 1995a, b). Over expression of tobacco osmotin and OSML13 from $S$. commersonnii in potato resulted in a delay in the development of symptoms (Liu et al. 1994; Zhu et al. 1996). Osmotin-like genes are also positional candidates for such loci, based on co-localization with late blight QTLs. PCR-based markers for the potato locus OSM-8 have been linked with a late blight QTL in the PD population, and markers for both the $O S M-8$ and $O S M-11$ loci tagged a QTL for late-blight resistance in the tetraploid progeny of a cross between the varieties Nikita and Leyla (Bormann et al. 2004). However, osmotin-like genes are not the only genes present in these genomic regions, and the discovery of other candidates may have to await the sequencing of the complete potato genome. In any case, the putative role of osmotin-like genes in the natural variation in resistance to late blight and other pathogens will require further validation. This can be approached by association mapping (Gebhardt et al. 2004; Simko et al. 2004) and ultimately by quantitative complementation analysis using different alleles.

Acknowledgements This work was supported by a grant (Project No. 96.7860.8-001.00) from the German Federal Ministry for Economic Cooperation and Development (BMZ). The authors are grateful to Ma. Del R. Herrera for providing the in vitro plant PD59 and DNA of the PD mapping population

\section{References}

Allouis S, Qi X, Lindup S, Gale M, Devos K (2001) Construction of a BAC library of pearl millet Pennisetum glaucum. Theor Appl Genet 102:1200-1205

Arumuganathan K, Earle E (1991) Nuclear DNA content of some important plants species. Plant Mol Biol Rep 9:208-218
Ballvora A, Ercolano M, Weiss J, Meksem K, Bormann C, Oberhagemann P, Salamini F, Gebhardt C (2002) The Rl gene for potato resistance to late blight (Phytophthora infestans) belongs to the leucine zipper /NBS/LRR class of plant resistance genes. Plant J 30:361-371

Bonierbale M, Simon R, Zhang D, Ghislain M, Mba C, Qing Li X (2003) Genomics and molecular breeding for root and tuber crop improvement. In: Newbury J (ed) Plant molecular breeding. Blackwell, Oxford, pp 216-253

Bonnema G, Hontelez J, Verkerk R, Zhang YQ, van Daelen R, van Kammen A, Zabel P (1996) An improved method of partially digesting plant megabase DNA suitable for YAC cloning: application to the construction of a 5.5 genome equivalent YAC library of tomato. Plant J 9:125-133

Bormann CA, Rickert AM, Castillo Ruiz RA, Paal J, Lübeck J, Strahwald J, Buhr K, Gebhardt C (2004) Tagging QTL for maturity-corrected late blight resistance in tetraploid potato with PCR-based candidate gene markers. Mol Plant Microbe Interact 17:1126-1138

Budiman MA, Mao L, Wood TC, Wing RA (2000) A deep-coverage tomato BAC library and prospects toward development of an STC framework for genome sequencing. Genome Res 10:129-136

Castillo-Ruiz RA (2002) A potato large insert library for isolation of candidate loci for late blight resistance and studies on their genome organziation. $\mathrm{PhD}$ Thesis, University of Cologne, Germany (available at http://kups.ub.uni-koeln.de/volltexte/ 2004/1067/)

Ercolano MR, Ballvora A, Paal J, Steinbiss H-H, Salamini F, Gebhardt C (2004) Biolistic transformation of plants with large DNA fragments: an efficient tool for functional complementation analysis in potato. Mol Breed 13:15-22

Faris JD, Li WL, Liu DJ, Chen PD, Gill BS (1999) Candidate gene analysis of quantitative disease resistance in wheat. Theor Appl Genet 98:219-225

Feinberg A, Vogelstein B (1984) A technique for radiolabelling DNA restriction endonuclease fragments to high specific activity (addendum). Anal Biochem 137:266-267

Fritjers A, Zhang Z, van Damme M, Wang G, Ronald P, Michelmore R (1997) Construction of a bacterial artificial chromosome library containing large EcoRI and HindIII genomic fragments of lettuce. Theor Appl Genet 94:390-399

Fritzemeier K, Cretin C, Kombrink E, Rohwer F, Taylor J, Scheel D, Hahlbrock K (1987) Transient induction of phenylalanine ammonia-lyase and 4-coumarate:CoA ligase mRNAs in potato leaves infected with virulent races of Phytophthora infestans. Plant Physiol 85:34-41

Gebhardt C, Valkonen JPT (2001) Organization of genes controlling disease resistance in the potato genome. Annu Rev Phytopathol 39:79-102

Gebhardt C, Ritter E, Debener T, Schachtschabel U, Walkemeier B, Uhrig H, Salamini F (1989) RFLP analysis and linkage mapping in Solanum tuberosum. Theor Appl Genet 78:65-75

Gebhardt C, Ritter E, Barone A, Debener T, Walkemeier B, Schachtschabel U, Kaufmann H, Thompson RD, Bonierbale MW, Ganal MW, Tanksley SD (1991) RFLP maps of potato and their alignment with the homologous tomato genome. Theor Appl Genet 83:49-57

Gebhardt C, Ritter E, Salamini F (2001) RFLP map of the potato. In: Phillips RL, Vasil IK (eds) DNA-based markers in plants (2nd edn) (Advances in cellular and molecular biology of plants, vol 6). Kluwer, Dordrecht, pp 319-336

Gebhardt C, Walkemeier B, Henselewski H, Barakat A, Delseny M, Stüber K (2003) Comparative mapping between potato (Solanum tuberosum) and Arabidopsis thaliana reveals structurally conserved domains and ancient duplications in the potato genome. Plant J 34:529-541

Gebhardt C, Ballvora A, Walkemeier B, Oberhagemann P, Schüler $\mathrm{K}$ (2004) Assessing genetic potential in germ plasm collections of crop plants by marker-trait association: a case study for potatoes with quantitative variation of resistance to late blight and maturity type. Mol Breed 13:93-102 
Geffroy V, Sevignac M, De Oliveira JCF, Fouilloux G, Skrotch P, Thoquet P, Gepts P, Langin T, Dron M (2000) Inheritance of partial resistance against Colletotrichum lindemuthianum in Phaseolus vulgaris and co-localization of quantitative trait loci with genes involved in specific resistance. Mol Plant Microbe Interact 13:287-296

Ghislain M, Trognitz B, Herrera M, Solis J, Casallo G, Vasquez C, Hurtado O, Castillo R Portal L, Orillo M (2001) Genetic loci associated with field resistance to late blight in offspring of Solanum phureja and Solanum tuberosum grown under shortday conditions. Theor Appl Genet 103:433-442

Hamilton CM, Frary A, Xu Y, Tanksley SD, Zhang H-B (1999) Construction of tomato genomic DNA libraries in a binaryBAC (BIBAC) vector. Plant J 18:223-229

Jones J, Schlumukov L, Carland F, English J, Scofield S, Bishop G, Harrison K (1992) Effective vectors for transformation, expression of heterologous genes, and assaying transposon excision in transgenic plants. Transgenic Res 1:285-297

Joos HJ, Hahlbrock K (1992) Phenylalanine ammonia-lyase in potato (Solanum tuberosum L.). Genomic complexity, structural comparison of two selected genes and modes of expression. Eur J Biochem 204:621-629

Kanyuka K, Bendahmane A, Rouppe van der Voort JNAM, van der Vossen EAG, Baulcombe DC (1999) Mapping of intralocus duplications and introgressed DNA: aids to map-based cloning of genes from complex genomes illustrated by analysis of the $R x$ locus in tetraploid potato. Theor Appl Genet 98:679689

Kombrink E, Somssich IE (1995) Defence responses of plants to pathogens. Adv Bot Res 21:1-34

Leister D, Ballvora A, Salamini F, Gebhardt C (1996) A PCR based approach for isolating pathogen resistance genes from potato with potential for wide application in plants. Nat Genet $14: 421-429$

Leonards-Schippers C, Gieffers W, Schafer-Pregl R, Ritter E, Salamini F, Gebhardt C (1994) Qualitative resistance to Phytophthora infestans in potato: a case study for QTL mapping in an allogamous plant species. Genetics 137:67-77

Li WL, Faris JD, Chittoor JM, Leach JE, Hulbert SH, Liu DJ, Chen PD, Gill BS (1999) Genomic mapping of defence response genes in wheat. Theor Appl Genet 98:226-233

Liu D, Raghothama K, Hasegawa P, Bressan R (1994) Osmotin overexpression in potato delays development of disease symptoms. Proc Natl Acad Sci USA 91:1888-1892

Martin GB, Ganal MW, Tanksley SD (1992) Construction of a yeast artificial chromosome library of tomato and identification of cloned segments linked to two disease resistance loci. Mol Gen Genet 233:25-32

McDowell JM, Woffenden BJ (2003) Plant disease resistance genes: recent insights and potential applications. Trends Biotechnol $21: 178-183$

Milbourne D, Meyer RC, Collins AJ, Ramsay LD, Gebhardt C, Waugh R (1998) Isolation, characterization and mapping of simple sequence repeat loci in potato. Mol Gen Genet 259:233245

Ming R, Moore P, Zee F, Abbey C, Ma H, Paterson A (2001) Construction and characterization of a papaya BAC library as a foundation for molecular dissection of a tree-fruit genome. Theor Appl Genet 102:892-899

Murashige T, Skoog F (1962) A revised medium for rapid growth and bioassay with tobacco tissue culture. Physiol Plant 15:473-497

Paal J, Henselewski H, Muth J, Meksem K, Menéndez CM, Salamini F, Ballvora A, Gebhardt C (2004) Molecular cloning of the potato Grol-4 gene conferring resistance to pathotype Rol of the root cyst nematode Globodera rostochiensis, based on a candidate gene approach. Plant J 38:285-297

Payne G, Middlesteadt W, Williams S, Desai N, Parks D, Dincher S, Carnes M, Ryals J (1988) Isolation and nucleotide sequence of a novel cDNA clone encoding the major form of pathogenesis-related protein R. Plant Mol Biol 11:223-224
Pflieger S, Palloix A, Caranta C, Blattes A, Lefebvre V (2001) Defence response genes co-localize with quantitative disease resistance loci in pepper. Theor Appl Genet 103:920-929

Pierpoint W, Jackson P, Evans R (1990) The presence of a thaumatin-like protein, a chitinase and a glucanase among the pathogenesis-related proteins of potato (Solanum tuberosum). Physiol Mol Plant Pathol 36:325-338

Ritter E, Gebhardt C, Salamini F (1990) Estimation of recombination frequencies and construction of RFLP linkage maps in plants from crosses between heterozygous parents. Genetics 125:645-654

Sambrook J, Fritsch E, Maniatis T (1989) Molecular cloning: a laboratory manual. Cold Spring Harbor Laboratory Press, Cold Spring Harbor

Simko I (2002) Comparative analysis of quantitative trait loci for foliage resistance to Phytophthora infestans in tuber-bearing Solanum species. Am J Potato Res 79:125-132

Simko I, Costanzo S, Haynes KG, Christ BJ, Jones RW (2004) Linkage disequilibrium mapping of a Verticillium dahliae resistance quantitative trait locus in tetraploid potato (Solanum tuberosum) trough a candidate gene approach. Theor Appl Genet 108:217-224

Song J, Dong F, Jiang J (2000) Construction of a bacterial artificial chromosome library for potato molecular cytogenetics research. Genome 43:199-204

Trognitz F, Manosalva P, Niño-Liu D, Herrera M, Ghislain M, Trognitz B, Nelson R (2002) Plant defence genes associated with quantitative resistance to potato late blight in Solanum phureja x Solanum tuberosum hybrids. Mol Plant Microbe Interact 15:587-597

Van Kan J, Van de Rhee M, Zuidema D, Cornelissen B, Bol J (1989) Structure of tobacco genes encoding thaumatin-like proteins. Plant Mol Biol 12:153-155

Van der Vossen E, Sikkema A, Hekkert B te L, Gros J, Stevens P, Muskens M, Wouters D, Pereira A, Stiekema W, Allefs S (2003) An ancient $R$ gene from the wild potato species Solanum bulbocastanum confers broad-spectrum resistance to Phytophthora infestans in cultivated potato and tomato. Plant J 36:867882

Velzhahan R, Datta S, Muthukrishnan S (1999) The PR-5 family: thaumatin-like proteins. In: Datta S, Muthukrishnan S (eds) Pathogenesis-related proteins in plants. CRC Press, Boca Raton, pp 107-129

Vinatzer B, Zhang H, Sansavini S (1998) Construction and characterization of a bacterial artificial chromosome library of apple. Theor Appl Genet 97:1183-1190

Wang Z, Taramino G, Yang D, Liu G, Tingey S, Miao G, Wang G (2001) Rice ESTs with disease-resistance gene- or defence-response gene-like sequences mapped to regions containing major resistance genes or QTLs. Mol Gen Genomics 265:302-310

Ward ER, Uknes SJ, Williams SC, Dincher SS, Wiederhold DL, Alexander DC, Ahl-Goy P, Metraux JP, Ryals JA (1991) Coordinate gene activity in response to agents that induce systemic acquired resistance. Plant Cell 31085-1094

Woo S, Jiang J, Gill B, Paterson A, Wing R (1994) Construction and characterization of a bacterial artificial chromosome library of Sorghum bicolor. Nucleic Acids Res 22:4922-4931

Zhang H, Zhao X, Ding D, Paterson A, Wing R (1995) Preparation of megabase-size DNA from plant nuclei. Plant J 7:175184

Zhu B, Chen T, Li P (1995a) Expression of three osmotin-like protein genes in response to osmotic stress and fungal infection in potato. Plant Mol Biol 28:17-26

Zhu B, Chen T, Li P (1995b) Activation of two osmotin-like proteins genes by abiotic stimuli and fungal pathogen in transgenic potato plants. Plant Physiol 108:929-937

Zhu B, Chen T, Li P (1996) Analysis of late-blight disease resistance and freezing tolerance in transgenic potato plants expressing sense and antisense genes for an osmotin-like protein. Planta 198:70-77 